\title{
POLA INTERAKSI GURU DAN ORANG TUA DALAM MENINGKATKAN KETERAMPILAN MOTORIK AUD SELAMA MASA PANDEMI COVID 19 DI TK AL IKHLAS
}

\author{
Nur Imam Mahdi, Misnan ${ }^{2}$, Yulfina Roza ${ }^{3}$, Erawati br Ginting ${ }^{4}$, Winda Lestari ${ }^{5}$ \\ ${ }^{1}$ Universitas Pendidikan Muhammadiyah Sorong, ${ }^{2,3,4,5}$ Sekolah Tinggi Agama Islam Sumatera Medan \\ Jl. Sambu No. 64, Kota Medan, Sumatera Utara \\ e-mail: imamlanglanghebat@gmail.com, misnan83@gmail.com, yulivinaroza0073@gmail.com, \\ gintingerawati01@gmail.com, windalestari.lh@gmail.com
}

\begin{abstract}
Abstrak: Penelitian ini bertujuan untuk menganalisis: (1) berbagai kesulitan dalam keberanian belajar, (2) pola kerjasama antara guru dan orang tua dalam meningkatkan keterampilan motorik anak, (3) hubungan yang meningkatkan kerjasama dalam meningkatkan keterampilan motorik anak. Metode penelitian yang digunakan adalah metode penelitian kualitatif, dengan pendekatan studi deskriptif. Hasil penelitian menunjukkan bahwa berbagai kesulitan belajar selama pandemi Covid-19 antara lain karena sulitnya guru dalam menentukan jenis kegiatan pembelajaran berbasis motorik pada anak, sulitnya guru menyusun indikator pembelajaran berbasis motorik, kesulitan dalam menilai perkembangan anak, kesulitan dalam menilai kejujuran anak dalam melaksanakan kegiatan pembelajaran motorik. Kedua kesimpulan rumusan masalah terkait pola interaksi guru dan orang tua dalam meningkatkan keterampilan motorik anak terdapat dua hal yaitu interaksi langsung dan interaksi tidak langsung, sedangkan simpanan orang tua kurang antusias, perbedaan pemahaman antara guru dan orang tua, internet jaringan tidak optimal, kesulitan dalam melaksanakan pembelajaran.
\end{abstract}

Kata Kunci: Interaksi, Keterampilan, Motorik, Pembelajaran

\begin{abstract}
This study aims to analyze: (1) various difficulties in learning courageously, (2) the pattern of cooperation between teachers and parents in improving children's motor skills, (3) relationships that increase cooperation in improving children's motor skills. The research method used is a qualitative research method, with a descriptive study approach. The results showed that the variety of learning difficulties during the Covid-19 pandemic, including because of the difficulty of the teacher in determining the type of motor-based learning activities for children, the difficulty of the teacher in compiling motor-based learning indicators, difficulty in assessing children's development, difficulty in assessing the honesty of children in carrying out activities motor learning. Both the conclusions of the second problem formulation related to the interaction patterns of teachers and parents in improving children's motor skills, there are two things that direct interaction and indirect interaction, while the less enthusiastic deposits of parents, different understanding between teachers and parents, internet networks not optimal, difficulties in implementing learning.
\end{abstract}

Keywords: Interaction, Skills, Motoric, Learning 


\section{PENDAHULUAN}

Pasca diberlakukannya kebijakan pemerintah (dalam hal ini kementerian pendidikan dan kebudayaan) terkait dengan pembelajaran secara daring atau jarak jauh selama masa pandemic Covid-19, tentu menuai banyak problematika baik di kalangan guru maupun di kalangan orang tua. Beberapa problematika terutama dirasakan oleh siswa yang masih duduk di bangku anak usia dini. Usia mereka tidaklah dapat melakukan pembelajaran secara mandiri, mereka membutuhkan pendampingan orang tua secara intens untuk melakukan pembelajaran. Berbeda halnya dengan jenjang pendidikan dasar dan menengah, walaupun mereka tetap membutuhkan pendampingan orang tua, namun tidak perlu se-intens yang dilakukan orang tua pada anak usia dini. (M. Lubis et al.).

Dari segala hal memang anak usia dini membutuhkan bantuan orang dewasa, dan ini telah menjadi sesuatu hal yang lazim. Jika tidak mendapatkan bantuan dari orang dewasa, maka akan ada masalah dengan perkembangan anak di masa mendatang. Masalah itu tentu saja anak tidak berkembang sebagaimana mestinya. Dalam kondisi ini ada kalanya orang tua berfungsi sebagai pengasuh, ada kalanya orang tua berfungsi sebagai pendidik. Dalam hal pengasuh, orang tua berperan dalam mengasuh anak dalam hal pertumbuhan fisiknya. Dalam hal pendidik, orang tua berperan dalam mengembangkan semua aspek perkembangan anak (secara mental dan kejiwaan. (Putro et al.).
Pendampingan kepada anak terus menerus secara kontinu dilakukan, sebab jika tidak maka akan ada pertumbuhan atau perkembangan yang gagal atau tidak sempurna pada diri anak. Oleh karena itu lah tak salah jika dikatakan bahwa mendidik anak dilakukan sejak dari lahir hingga ia masuk kedalam liang lahat. Kalam hikmah itu sekaligus mengajarkan kepada orang tua, bahwa sepanjang masa orang selalu mengalami pertumbuhan dan perkembangan, maka dari itu sejak dini anak memang sudah di arahkan kepada perkembangan-perkembangan yang dimaksud. (Ayun)

Para pakar mengatakan bahwa masa usia dini adalah masa golden age (Usia keemasan) disebut demikian karena pada masa ini terjadi banyak sekali pertumbuhan dan perkembangan, bahkan masa keunggulan untuk melatih dan mendidik perkembangan anak. (Sit). Itu lah sebabnya tak heran terlihat bahwa pada masa usia dini anak sangat mudah untuk mengingat dan meniru sesuatu, bahkan terkadang sering kita membbandingkanya dengan kemampuan orang dewasa, yang mungkin di satu sisi berbeda kemampuan. Anak usia dini yang dikontrol sejak dini akan menghantarkannya pada pencapaian manusia yang sempurna. (Ayuni et al.).

Banyak aspek yang perlu dikembangkan pada anak usia dini, di antaranya aspek kognitif, aspek sosial, aspek emosional, aspek motoric kasar, aspek motoric halus, aspek keterampilan berbicara, aspek spiritual, aspek Bahasa, dan aspek seni. Selruruh aspek yang telah disebutkan di atas menjadi prioritas dalam 
mengarahkan tumbuh kembang anak, namun seperti yang telah dijelaskan di atas seluruh perkembagan itu juga harus diarahkan sesuai dengan masa usia mereka. (Mansyur).

Dalam praktiknya orang tua tentu tidaklah dapat memikul beban (mendidik anak) sendiri, ia memerlukan bantuan orang lain untuk membantunya. Sebab tentu tidak semua orang tua mampu untuk mendidik anak mereka, sebagaimana yang di inginkan. Dalam kondisi ini guru adalah sosok yang tepat untuk membantu orang tua. Dengan memasukkan anak ke lembaga pendidikan maka orang tua dapat terbantu dalam menyelesaikan urusan didikan anak tersebut. (Kurniati et al.).

Disekolah anak akan dididik, di arahkan, dan ditumbuhkembangkan segala aspek sebagaimana yang telah disebutkan di atas. Bahkan bedanya dengan dirumah, sekolah memiliki perencanaan, pelaksanaan, dan pengawasan yang matang terkait dengan didikan tersebut. Tersedia kurikulum, Metode, media, evaluasi, bahkan sarana dan prasarana yang mendukung ketercapaian pengembangan aspek juga disediakan. (Lubis and Rusadi). Anak hanya tinggal di antar kesekolah, dan tinggal selama beberapa jam disekolah untuk ikut belajar (bermain) bersama dalam hal pengembangan aspek kecerdasan sebagaimana dimaksud di atas. (Donatirin).

Namun semua itu seolah berubah sedemikiannya cepatnya ketika muncul wabah pandemi Covid-19. Pembelajaran yang selama ini dapat dilakukan di sekolah, kini harus dilakukan penuh di rumah, pembelajaran yang dulunya dilakukan dengan guru secara tatap muka di dalam kelas, dan dapat berceramah dengan bebas di depan kelas, (Hanum) kini harus secara jarak jauh lewat media virtual. (R. R. Lubis, Mahrani, et al.). Tentu ada banyak problem yang dihadapi dengan perubahan sistem pembelajaran ini. Ada beberapa aspek yang memungkinkan untuk dijelaskan atau diarahkan lewat media virtual, akan tetapi ada aspek yang sulit untuk dijelaskan atau diajarkan lewat media virtual, yakni aspek motorik. Aspek motorik berkaitan dengan kemampuan gerak anak, atau berkaitan dengan keterampilan anak dalam melakukan sesuatu hal. (Firman and Rahayu).

Pembelajaran pada aspek motorik memang menghendaki anak untuk mempraktikkannya secara langsung, dan menghendaki guru untuk dapat mengamati praktik itu secara langsung pula. Jika pembelajaran itu dilakukan secara tatap muka tentu tidak akan ada permasalahan, akan tetapi saat ini aturan pemerintah tidak memungkinkan untuk saling melakukan pembelajaran secara tatap muka, sehingga proses pengamatan terhadap hasil praktik siswa sulit rasanya untuk dilakukan. Jika tidak diamati secara langsung tentu tidak akan dapat disimpulkan sejauh mana sudah kemampuan motorik anak tersebut. Belum lagi ketika dalam melakukan praktik yang diminta oleh guru dan ternyata ada kesalahan maka tidak secara virtual tentu akan mnyulitkan untuk memberitahu kesalahan dan memberitahu cara memperbaikinya. (Windarsih).

Dalam kondisi seperti ini satusatunya sosok yang dapat memantau 
praktik tersebut ialah orang tua, baik ibu ataupun ayah yang menjadi pendamping anak dalam mengikuti pembelajaran. Hanya saja tidak semua orang tua dengan serta merta mengerti letak kesalahan tersebut, dan tidak semua orang tua mengerti cara memperbaikinya, dan bahkan lebih dari itu tidak semua orang tua memiliki waktu penuh untuk mendampingi anak dalam belajar. Maka dalam hal ini tentu kerjasama orang tua dan guru menjadi sangat penting untuk disinergikan, sebab jika tidak anak akan kesulitan dalam melakukan pembelajaran sebagaimana yang telah diberikan oleh guru, dan tentu muaranya akan menghambat perkembangan peserta didik. (Dewi).

Berdasarkan permasalahan di atas maka fokus penelitian ini dikhusus untuk menganalisis beberapa hal yakni: (1) ragam kesulitan dalam pembelajaran secara daring, (2) Pola kerjaasama antara guru dan orang tua dalam meningkatkan keterampilan motorik anak, (3) kendala yang dihadapi dalam kerjasama peningkatan keterampilan motoric anak.

\section{METODE PENELITIAN}

Metode yang digunakan dalam penelitian ini ialah metode penelitian kualitatif, berbasis pendekatan studi deskriptif. Creswell menjelaskan bahwa studi deskriptif menghendaki pendeskripsian temua penelitian secara nyata berdasarkan temuan dan fakta di lapangan. Namun tidak dapati dipungkiri bahwa penelitian ini juga di warnai dengan interpretasi penulis terhadap pengamatan yang dilakukan, dengan tujuan untuk lebih memperdalam analis pembahasan.

Penelitian ini dilakukan di TK AL Ikhlas Padang Bulan Medan, yang beralamat di Jalan Padang Bulan Kota Medan, Sumatera Utara. Penelitian ini dilakukan dalam kurun waktu dua bulan, yakni dari bulan agustus hingga bulan September 2020. Pelaksanaan penelitian menyesuaikan dengan kesiapan subjek penelitian, di antaranya seperti pada saat selesai pembelajaran daring, pada saat hari libur (dengan tujuan tidak ingin menggangu jam pembelajaran), dan terkadang juga dilakukan di sela-sela pembelajaran berlangsung, namun dalam hal ini pemilihan waktu menjadi hak dari subjek penelitian.

Sumber data yang digunakan dalam penelitian ini ialah guru, orang tua, dan siswa. Secara rinci seperti tertera di bawah ini:

1. Guru, sumber data yang akan diperoleh dari guru yakni berkaitan dengan ragam kesulitan pembelajaran yang dihadapi selama pembelajaran berbasis daring, dan juga diperoleh informasi seputar bentuk-bentuk pembelajaran yang mengarahkan pada peningkatan kecerdasan motorik anak, dan juga pola-pola kerjasama dengan orang tua dalam meningkatkan keterampilan motorik anak.

2. Orang tua, pada orang tua akan diperoleh informasi seputar ragam kesulitan yang dihadapi sebagai pendamping anak selama pembelajaran berbasis daring, dan juga bagaimana kendala yang dihadapi dari kerjasama 
yang telah dilaksanakan selama ini bersama dengan guru terkait dengan pembelajaran dengan fokusnya pada peningkatan kecerdasan motorik anak

3. Siswa, pada diri siswa akan diperoleh informasi seputar kegiatan-kegiatan pembelajaran yang mereka lakukan terkait dengan peningkatan kecerdasan motorik, dana pa saja kendala yang mereka hadapi terkait dengan sistem pembelajaran yang seperti saat ini.

Adapun teknik pengumpulan data yang dilakukan ialah sebagai berikut:

4. Wawancara, wawancara dalam hal ini dilakukan kepada guru, orang tua, dan juga siswa terkait dengan ragam bentuk pembelajaran yang digunakan, kendala yang dihadapi, dan respon para subjek penelitian terhadap pembelajaran di masa pandemi Covid-19

5. Observasi,observasi dilakukan dengan cara mengamati secara tak langsung terhadap kegiatan pembelajaran siswa. Dikatakan tidak langsung karena dalam hal ini peneliti tidak bertemu langsung dengan subjek penelitian, akan tetapi bertemu lewat media virtual saja, dengan demikian pengamatan di lihat berdasarkan aktivitas pembicaraan langsung menggunakan whatss app, atau zom, atau bisa juga hasil penugasan yang telah dikirimkan kepada guru dalam bentuk rekaman lantas kemudian di amati untuk diinterpreasikan secara analisis desriptif

6. Dokumentasi, dokumentasi ini merupakan teknik untuk mengumpulkan data berdasarkan dokumen-dokumen yang dipergunakan, sperti dalam hal ini dokumen perangkat pembelajaran guru seperti rencana pembelajaran harian, dan rencana pembelajaran mingguan, dan juga dokumen tentang hasil evaluasi pembelajaran siswa terkait dengen penilaian progress peningkatan keterampilan motoric anak.

Adapun eknik analisis data yang dipergunakan dalam penelitian ini ialah analisis deskriptif. Maksudnya analisa temuan penelitian dalam bentuk pendeskripsian. Analisis dalam hal ini yang dimaksud dengan interpretasi dari penulis. Untuk menjamin keabsahan data penelitian ini menggunakan teknik pengujian kredibilitas (kepercayaan), transferabilitas (keterlibatan), dependabilitas (kebergantungan), dan konfirmabilitas (kepastian) yang terkait dengan proses pengumpulan dan analisis data. (R. R. Lubis, Hasibuan, et al.).

\section{HASIL DAN PEMBAHASAN}

Hasil dan pembahasan penelitian akan dikemukakan berdasar urutan fokus penelitian sebagaimana yang tertuang pada bagian pendahuluan:

1. Ragam kesulitan pembelajaran selama masa pandemic Covid-19

Sebagaimana yang telah disebutkan sebelumnya bahwa pembelajaran pada masa pandemic Covid-19 menimbulkan banyak permasalahan baik dikalangann guru, siswa, dan juga orang tua. Namun secara rinci permasalahan yang akan dikemukakan di bawah ini khusus yang berkaitan dengan ksulitan dalam hal aspek 
pembelajaran motorik saja, yakni sebagai berikut:

a. Kesulitan dalam menentukan jenis kegiatan pembelajaran motorik anak Pada saat pandemic Covid-19 guru memang sangat mengalami kesulitan dalam menentukan jenis kegiatan pembelajaran motorik anak. Hal ini dikarenakan tidak semua bentuk kegiatan dapat diterapkan dan dilakukan dengan oleh anak dengan model pembelajaran daring. Intinya terdapat dua permasalahan dalam hal ini yaitu ketidaksesuaian dengan kondisi sistem pembelajaran, ketidaksesuaian dengan kemampuan anak. Atas dasar kesulitan ini kerap kali guru memberikan pembelajaran peningkatan motorik yang berbeda dengan silabus atau rencana pembelajaran yang telah ditetapkan.

Berdasarkan pengamatan peneliti terhadap kegiatan pembelajaran (rekaman video), menunjukkan banyak pembelajaran peningkatan motorik yang dimodifikasi sesuai dengan dengan kebutuhan dam kondisi siswa. Hal ini untuk memudahkan siswa dan orang tua dalam melaksanakan pembelajaran yang diberikan guru. Misalnya saja senam berkelompok, kini di rubah menjadi senam di individu yang dilaksanakan di rumah masingmasing.

b. Kesulitan dalam menyusun indikator pembelajaran berbasis motorik

Indikator pembelajaran merupakan tolak ukur keberhasilan pembelajaran, dan masing-masing aspek memiliki perbedaan dalm indikatornya. Khusus untuk pembelajaran motorik tentu indikator pembelajarannya menghendaki kemampuan anak untuk terampil dalam melakukan gerak ataupun sesuatu kegiatan. Dikarenakan pandemi Covid-19 dan pembelajaran yang dilaksanakan secara jarak jauh, membuat guru sulit untuk menetapkan indikator pembelajaran, sebab jika secara ideal dan normatif tentu akan sulit untuk dipenuhi oleh siswa, akhirnya indikator pembelajaran pun tidak sesuai dengan silabus dan kurikulum yang ada. Penyesuaian pun dilakukan guru dengan mendasarkannya pada kegiatan pembelajaran yang sudah dilakukan. Hal ini sebebenarnya berbeda dengan ketentuan yang ada, seperti yang dikelaskan oleh Atwi Suparman bahwa penyusuanan indikator pembelajaran itu dilakukan pada saat merencanakan pembelajaran, yang didasarkan pada tujuan pembelajaran yang telah di tetapkan.

Namun dikarenakan tidak tetapnya kondisi suasana dan kemampuan anak dalam mengikuti pembelajaran di tengah kondisi pandemi ini, akhirnya indikator pun disusun berdasarkan sudah sejauh mana pembelajaran itu diajarkan. Tentu saja pada muara akhirnya pembelajaran yang dijalankan tidak mencapai tujuan pembelajaran secara penuh seperti apa yang tertuang dalam kurikulum yang ditetapkan oleh pemerintah. 
c. Kesulitan dalam menilai perkembangan motorik anak

Kondisi jarak jauh, dan tidak adanya guru saat anak mendemonstrasikan kegiatan motorik sebagaimana yang diperintahkan guru akhirnya memberikan kesulitan bagi guru dalam menentukan nilai perkembangan motorik anak. Kesulitan ini lebih dititikberatkan pada tidak teramatinya secara keseluruhan gerakan-gerakan yang dilakukan oleh anak. Jika tidak teramati secara keseluruhan maka penilaian tidak dapat dilakukan dengan maksimal, dan dalam hal ini guru khwatir jika pemberian nilai tidak tepat sebagaimana yang di lakukan.

d. Kesulitan dalam menilai kejujuran anak melakukan kegiatan pembelajaran motorik

Pembelajaran daring memang menghendaki orang tua sebagai pendamping anak di rumah. Jika selama ini pembelajaran dilakukan di kelas bersama dengan siswa lainnya dan di bimbing serta di awasi langsung oleh guru. Kini peran itu digantikan oleh orang tua di rumah. Dalam hal kegiatan pembelajaran di rumah tentu dalam hal ini dikarenakan tidak berada dekat dengan anak, dan hanya dapat mengawasinya lewat virtual, tentu tidak dapat secara maksimal orang tua memantau perkembagan anak, terutama dalam hal pembelajaran yang sifatnya mengandalkan aspek psikomotorik.

Dikatakan sulit karena dalam hal ini guru sulit untuk menilai kejujuran anak, sebab tidak menutup kemungkinan dalam ha ini orang tualah yang memabantu anak untuk mengerjakan segala tugas ataupun ujian yang diberikan kepada anak. Sebenarnya dalam hal ini orang tua memang berfungsi sebagai pendamping, hanya saja terkadang istilah pendamping disalahmaknai oleh orang tua, demi hasil belajar yang baik, maka tak jarang dari orang tua yang sampai memberikan bantuan lebih kepada anaknya

2. Pola Interaksi guru dan orang tua dalam meningkatkan keterampilan motorik anak

Keterampilan motorik merupakan salah satu tujuan pembelajaran yang harus dimiliki anak sejak usia dini. Keterampilan motorik di bagi menjadi dua, yakni keterampilan mororik kasar, dan keterampilan motorik halus. Keduakeduanya menjadi perhatian khusus sejak masa usia dini. Tatkala pembelajaran berlangsung normal, dalam arti sebelum masa pandemic Covid-19, tidak ada permasalahan serius terkait dengan model pembelajaran untuk aspek motorik anak. Akan tetapi keberadaan Covid-19 cukup membuat orang tua dan guru memeras pikiran mencari cara bagaimana agar pembelajaran dapat terlaksana dengan baik. Oleh karena pembelajaran dilaksanakan di rumah, dan orang tua menjadi pendampingnya maka interaksi orang tua dan guru sangat diperlukan untuk hal ini.

Beberapa pola interaksi yang teramati pada TK Al Ikhlas Padang Bulan Medan sebagai berikut:

a. Interaksi langsung 
Interaksi langsung maksudnya dalam hal ini ialah interaksi yang dilakukan lewat komunikasi secara langsung baik menggunakan jaringan internet atau jaringan telefon. Interaksi ini dilakukan guru untuk memandu orang tua dalam mengajarkan pembelajaran yang sifatnya motorik kepada anak. Pemanduan ini diperlukan karena pembelajaran berkaitan dengan gerakan-gerakan tertentu dan teratur yang perlu dikuasai oleh anak. Seperti kegiatan senam, kegiatan menari, menggunting dan menempel pola, dan sebagainya. Pada TK ini guru memang memberikan tugas untuk anak, akan tetapi tentu saja anak tidak akan dapat melakukannya secara mandiri tanpa ada bantuan dari orang tua. Itulah sebabnya orang tua yang harus diberikan pemahan terlebih dahulu sebelum orang tua memerintahkan anaknya untuk melakukan tugas sebagaimana yang dimaksudkan guru.

Interaksi ini menjadi interaksi yang sering dilakukan untuk kegiatan motorik yang sifatnya kompleks dan perlu keteraturan, seperti misalnya dalam hal ini sebagaimana yang berhasil penulis amati ialah senam pagi. Sebelum adanya Covid anak-anak di TK Al Ikhlas Padang Bulan Medan, terbiasa untuk melakukan senam pagi, tujuannya selain untuk kebugaran bertujuan juga untuk melatih perkembangan motorik mereka.

Pola ini memang kerap memberikan kesulitan tersendiri pada orang tua, sebab secara tak langsung orang tua yang memiliki peran sebagai guru, dan dikarenakan situasi dan kondisi membuat orang tua tidak memili kemampuan untuk dapat menolaknya. Akhirnya mau tidak mau memang harus diterima oleh orang tua. Karena dengan alasan kesulitan itu maka peran guru dalam hal ini mengajak orang tua untuk berinteraksi langsung terkait dengan hal yang harus dipraktikkan anak di rumah.

b. Interaksi tidak langsung

Interaksi secara tidak langsung maksudnya dalam hal ini ialah interaksi guru dan orang tua tidak secara langsung berkomunikasi, namun interaksi ini dalam bentuk pemberian panduan secara tertulis. Ketika guru memberikan tugas berupa pembelajaran motorik, guru memberikan arahan melalui pesan yang tertulis, dalam arti prosedur atau langkah-langkah pelaksanaan pembelajarannya dilakukan dengan cara mengikuti langkah-langkah yang telah disampaikan oleh guru lewat pesan.

Interaksi tidak langsung ini dilakukan khusus pada materi pelajaran motorik yang sifatnya tidak terlalu kompleks, dalam arti tidak membutuhkan keteraturan yang sangat detail. Seperti misalnya menggunting pola, menempel pola tertentu pada sketsa gambar yang tersedia dan sebagainya. Kegiatan ini memang tidak lah membutuhkan keteraturan mendalam, akan tetapi memang memerlukan bantua orang tua untuk melakukannya, sebab itulah makanya 
guru memberikan arahan dan aturan lewat pesan saja.

Interaksi tidak langsung bukan berarti membuat guru tidak memiliki peran sama sekali dalam hal ini, hanya saja perannya berkurang karena hanya disampaikan lewat pesan baik melalui internet dan ataupun pesan singkat. Interaksi ini memang tidaklah begitu Nampak akan tetapi interaksi ini membutuhkan keseriusan dalam memahami pesan yang disampaikan oleh guru, sebab jika tidak maka akan terjadi kesalahan dalam pemahaman tugas yang diberikan oleh guru.

3. Kendala yang dihadapi dalam kerjasama peningkatan keterampilan motorik anak

Kendala yang dihadapi dalam kerjasama orang tua dan guru memang tidaklah begitu tampak akan tetapi, kendala ini jika tidak mendapatkan perhatian maka akan mempengaruhi perkembangan motorik anak. Beberapa kendala tersebut sebagai berikut:

a. Kurangnya antusiasnya orang tua

Kurangnya antusias orang tua terhadap kegiatan pembelajaran memang memberikan dampak yang signifikan terhadap hasil belajar siswa, terutama dalam keterampilan motorik. Kurangnya antusias ini memang dikarenakan karena kesibukan pekerjaan orang tua. Selama pembelajaran daring orang tua memang menjadi pendamping bagi anak, akan tetapi ketika pembelajaran itu menghendaki interaksi langsung maka terdapat beberapa orang tua yang tidak bisa aktif dalam kegiatan pembelajaran.

Bahkan kondisi ini telah disampaikan oleh orang tua secara langsung bahwa ia tidak dapat mengikuti pembelajaran sebagaimana yang jadwal yang telah di tentukan oleh guru. Alhasil pembelajaran tersebut dilakukan dengan waktu yang berbeda dengan waktu guruguru lainnya. Waktu lain itu pun terkadang pada sisi guru malah tidak bisa terlaksana, sebab pada waktu di luar jadwal tersebut terdapat beberapa guru yang memiliki kesibukan pula.

Sikap tidak antusias ini memang tidak dirasakan sekali, akan tetapi dirasakan beberapa kali orang tua, sehingga kerap kadang membuat guru menjadi kesulitan dalam memetakan pencapaian hasil pembelajaran sebab, ketidaktercapaian pembelajaran bukan karena tidak tercapainya pembelajaran. Akan tetapi karena ketidakikutsertaan dalam mengikuti pembelajaran. Dikatakan demikian karena sikap tidak antusias memang tidak hanya membuat siswa tidak aktif, bahkan sampai pada tidak mengikuti pembelajaran. (Lubis and Nasution).

b. Berbeda pemahaman antara guru dan orang tua

Terkadang dalam pembelajaran memang terjadi perbedaan pendapat antara orang tua dan guru, terutama dalam penentuan teknis pembelajaran. Seperti pemilihan jenis aplikasi pembelajaran, dan kadang kala juga berbeda memilih pola pengiriman tugas. Dan memang dari pengamatan tampak bahwa rerata permasalahan ini muncul pada 
pembelajaran yang sifatnya motorik. Sebenarnya permasalahan tentang perbedaan pemahaman ini pada pembelajaran motorik dikarenakan memang orang tua memiliki peran sentral dalam pembelajaran tersebut, sebab terlaksana tugas yang diberikan guru atau tidaknya tergantung bagaimana orang tua memberikan dampingan dan mengirimkan laporan kepada guru.

Perbedaan pemahaman ini tentu menjadikan tujuan yang sebagaimana mestinya direncakanan orang tua menjadi tidak maksimal, sebab ada beberapa kegiatan pembelajaran yang tidak dilakukan secara penuh. Seperti yang penulis amati misalnya pada pembelajaran tentang gerakan motorik kasar seperti senam pada pagi hari, dalam hal ini guru meminta siswa untuk mempraktikkanya kemudian di rekam viedeonya kemudian di kirimkan kepada guru, akan tetapi beberapa di antara orang tua yang tidak setuju dengan hal itu, dikarenakan menurut mereka terlalu lama untuk di rekam, dan akan terlalu banyak menghabiskan paket internet.

Tentu saja kejadian ini membuat orang tua tidak mengirimkan tugas anaknya dan anak pun pada akhirnya tidak mengikuti kegiatan pembelajaran sebagaimana dilaksanakan oleh temanteman lainnya. Pad akhirnya terdapat beberapa kompetensi anak yang tidak di kuasainya. Dalam hal ini akan menjadi tambahan tugas bagi guru untuk memperbaiki kondisi tersebut, (Lubis) maka diperlukanlah pendekatan persuasif atau bahkan merubah strategi pembelajaran dari yang sebelumnya sudah ditetapkan pada strategi lain yang mungkin dapat lebih diterima oleh semuanya. Perubahan strategi pembelajaran ini memang sebagai wujud dari inovasi pendidikan yang dilakukan di masa pandemi.(R. R. Lubis, Irwanto, et al.). c. Jaringan internet yang tidak maksimal

Jaringan internet juga menjadi kendala interaksi orang tua dan guru, sebab interaksi hanya dapat dilakukan secara online. (Rusadi et al.). Tidak dapat dilakukan secara tatap muka, jika pun dapat dilakukan secara tatap muka (dikarenakan rumah guru dan orang tua tidak berjauhan) akan tetapi Jaringan internet juga menjadi kendala interaksi orang tua dan guru, sebab interaksi hanya dapat dilakukan secara online. Tidak dapat dilakukan secara tatap muka, jika pun dapat dilakukan secara tatap muka (dikarenakan rumah guru dan orang tua tidak berjauhan) akan tetapi tentu tidak membicarakan hal-hal yang bersifat pelajaran. Jaringan internet yang buruk terkadang membuat komunikasi orang tua dan guru menjadi terhambat bahkan terkadang seringkali komunikasi yang senang dilakukan terputus karena jaringan internet yang tidak maksimal. akhirnya kondisi ini membuat interaksi antara orang tua dan guru menjadi tidak maksimal, terlebih problem ini terjadi pada saat pembelajaran berbasis motorik. kondisi ini kerap terjadi pada saat kondisi cuaca yang buruk atau pada saat menggunakan aplikasi yang memang membutuhkan jaringan internet yang tinggi. Untuk mengatasi masalah ini biasanya guru membagi ruang pembelajaran menjadi dua sesi, tujuannya untuk mengantisipasi 
terjadinya kegagalan jaringan, atau solusi lain urut berinteraksi dengan orang tua tidak melalui jaringan internet akan tetapi menggunakan jaringan seluler.

d.
pembulitan dalam penerapan

Kendala Interaksi antara guru dan orang tua juga terjadi karena sulitnya orang tua menerapkan langkah pembelajaran yang telah dijelaskan oleh guru. kesulitan ini terjadi karena langkahlangkah penerapan tersebut disampaikan Dalam bentuk pesan Whatsapp atau juga dalam bentuk rekaman video atau dengan kata lain langkah-langkah penerapan tersebut disampaikan dengan cara tidak langsung. kekurangan penyampaian dengan cara tidak langsung ini Iyalah orang tua tidak dapat bertanya secara langsung terkait dengan hambatan ataupun kendala yang mereka hadapi saat memahami langkah-langkah pembelajaran yang telah dilakukan oleh guru. Hasil pengamatan menunjukkan tidak sedikit dari orangtua yang mengalami permasalahan dalam memahami langkah-langkah penerapan pembelajaran terkhusus pada pembelajaran yang sifatnya motorik. Sebagaimana diketahui bahwa pembelajaran bersifat aspek motorik memang sarat dengan runtutan langkah-langkah penerapan jika ada satu atau beberapa saja penerapan tidak terlaksana atau Terlewatkan maka tujuan akhir dari pembelajaran tersebut tidak akan tercapai.

sebagai bukti bahwa beberapa orang tua mengalami kesulitan dalam penerapan pembelajaran berbasis motorik, didapati beberapa orang tua sering terlambat mengirimkan tugas anaknya bahkan ada beberapa siswa yang menurut pengakuannya tidak mengirimkan tugas pembelajaran kepada guru dikarenakan tidak mengerti atau kurang paham dengan penjelasan yang telah disampaikan oleh guru baik lewat rekaman ataupun lewat pesan di WhatsApp. kondisi ini tentu mempengaruhi ketercapaian tujuan pembelajaran sebagaimana yang ditentukan di dalam rencana pembelajaran harian atau di dalam silabus pembelajaran.

Kerapkali beberapa orangtua mengajukan kritik ataupun protes kepada guru tatkala langkah-langkah penerapan yang disampaikan lewat rekaman ataupun pesan Whatsapp tidak jelas ataupun kurang detail. untuk mengantisipasi maka setelah memberi penjelasan dan ajaran bersifat aspek motorik, lagi memberi ruang kepada orang tua untuk bertanya secara pesan pribadi. Namun perlu diketahui bahwa tidak semua kesulitan yang dialami orang tua dalam penerapan pembelajaran dikarenakan sulitnya orang tua memahami penjelasan penjelasan yang melalui rekaman, Akan tetapi kesulitan tersebut dikarenakan memang orang tua sedikit lambat dalam memahami penjelasan yang disampaikan oleh guru sebab jika lah memang dikatakan Bahwa kesulitan itu dikarenakan kurang baiknya guru Dalam mengemas penjelasan lewat WhatsApp tentu akan dialami oleh seluruh orang tua siswa, akan tetapi kenyataannya tidak demikian hanya beberapa orangtua saja yang mengalami kesulitan dalam memahami penerapan tersebut sehingga dalam hal ini dapat penulis katakan bahwa 
kesulitan itu dikarenakan oleh dua hal yakni pertama karena Kesulitan yang disebabkan karena kurangnya pemahaman orang tua dan kedua karena kesulitan yang disebabkan karena kuarang baiknya guru dalam mengemas pembelajaran.

\section{SIMPULAN}

Berdasarkan penjelasan di atas dapat disimpulkan berdasarkan rumusan masalah yang ada bahwa Ragam kesulitan pembelajaran selama masa pandemic Covid-19, di antaranya karena sulinta guru dalam menentukan jenis kegiatan pembelajaran berbasis motorik anak, sulitnya guru dalam menyusun indikator pembelajaran berbasais motorik, sulitnya dalam menilai perkembanagan anak, kesulitan dalam menilai kejujuran anak melakukan kegiatan pembelajaran motorik. Kemudian simpulan rumusan masalah kedua yakni berkaitan dengan pola Interaksi guru dan orang tua dalam meningkatkan keterampilan motorik anak, terdapat dua hal yakni interaksi langsung, dan interaksi tidak langsung, sedangkan kendala yang dihadapi ialah kurangnya antusiasnya orang tua, berbeda pemahaman antara guru dan orang tua, jaringan internet yang tidak maksimal, kesulitan dalam penerapan pembelajaran

\section{DAFTAR PUSTAKA}

Ayun, Qurrotu. "Pola Asuh Orang Tua dan Metode Pengasuhan Dalam Membentuk Kepribadian Anak." Journal Ta'dib, vol. 3, no. 1, 2018, p. 15.
Ayuni, Despa, et al. "Kesiapan Guru TK Menghadapi Pembelajaran Daring Masa Pandemi Covid-19." Jurnal Obsesi: Jurnal Pendidikan Anak Usia Dini, vol. 5, no. 1, 2020, pp. 414-21.

Dewi, Wahyu Aji Fatma. "Dampak Covid19 Terhadap Implementasi Pembelajaran Daring Di Sekolah Dasar." Edukatif: Jurnal Ilmu Pendidikan, vol. 2, no. 1, 2020, pp. 55-61, https://doi.org/10.31004/edukatif.v2i1. 89.

Donatirin, Siti. "Pembelajaran yang Sesuai dengan Perkembangan Anak (Developmentally Appropriate Practice/DAP)." IPABI, 2009, p. 1, http://ipabi.org/pembelajaran-yangsesuai-dengan-perkembangan-anakdevelopmentally-appropriatepracticedap/.

Firman, Firman, and Sari Rahayu. "Pembelajaran Online Di Tengah Pandemi Covid-19." Indonesian Journal of Educational Science (IJES), vol. 2, no. 2, 2020, pp. 81-89, doi:10.31605/ijes.v2i2.659.

Hanum, Latifah. "Analisis Strategi Pembelajaran Active Knowledge Sharing Dan Ceramah Terhadap Hasil Belajar Pendidikan Agama Islam." Fitrah: Journal of Islamic Education, vol. 1, no. 1, 2020, pp. 36-54, http://jurnal.staisumateramedan.ac.id/index.php/fitrah/article/vi ew/5.

Kurniati, Euis, et al. "Analisis Peran Orang Tua Dalam Mendampingi Anak Di Masa Pandemi Covid-19." Jurnal Obsesi: Jurnal Pendidikan Anak Usia Dini, vol. 5, no. 1, 2020, pp. 241-56, https://doi.org/10.31004/obsesi.v5i1.5 41.

Lubis, Masruroh, et al. "Pembelajaran Pendidikan Agama Islam Berbasis ELearning (Studi Inovasi Pendidik 
MTS. PAI Medan di Tengah Wabah Covid-19)." Fitrah: Journal of Islamic Education, vol. 1, no. 1, 2020, pp. 115, http://jurnal.staisumateramedan.ac.id/index.php/fitrah/article/vi ew/1.

Lubis, Rahmat Rifai, Irwanto Irwanto, et al. "Increasing Learning Outcomes and Ability Critical Thinking of Students Through Application Problem Based Learning Strategies." International Journal for Educational and Vocational Studies, vol. 1, no. 6, 2019, pp. 524-27.

Lubis, Rahmat Rifai. "Kompetensi Kepribadian Guru dalam Persfektif Islam (Studi Pemikiran Nasih 'Ulwān dalam Kitab Tarbiyatul Aulād)." Tazkiya, vol. 5, no. 2, 2016, pp. 1-13, http://jurnaltarbiyah.uinsu.ac.id/index. php/tazkiya/article/viewFile/83/67.

Lubis, Rahmat Rifai, Nurhayati Hasibuan, et al. "Model-Model Permainan Aud Di Rumah (Studi Deskriptif Di Tk Aisyiyah Kp Dadap Selama Masa Pandemi Covid-19)." Kumara Cendekia, vol. 8, no. 3, 2020.

Lubis, Rahmat Rifai, Nana Mahrani, et al. "Pembelajaran Al-Qur'an Era Covid19: Tinjauan Metode dan Tujuannya Pada Masyarakat Di Kutacane Aceh Tenggara." Kuttab, vol. 4, no. 2, 2020.

Lubis, Rahmat Rifai, and Miftahul Husni Nasution. "Implementasi Pendidikan Karakter di Madrasah." JIP (Jurnal Ilmiah PGMI), vol. 3, no. 1, 2017, pp. 15-32.

Lubis, Rahmat Rifai, and Bobi Erno Rusadi. "Problematika Implementasi Scientific Approach dalam Pembelajaran Fikih (Studi Kasus Di MTs. PAI Medan)." Intiqad: Jurnal Agama Dan Pendidikan Islam, vol. 11, no. 1, 2019, pp. 118-34.
Mansyur, Abd Rahim. "Dampak Covid-19 Terhadap Dinamika Pembelajaran Di Indonesia." Education and Learning Journal, vol. 1, no. 2, 2020, p. 113, doi:10.33096/eljour.v1i2.55.

Putro, Khamim Zarkasih, et al. "Pola Interaksi Anak dan Orangtua Selama Kebijakan Pembelajaran Di Rumah." Fitrah: Journal of Islamic Education, vol. 1, no. 1, 2020, pp. 124-40.

Rusadi, Bobi Erno, et al. "Analisis Learning and Inovation Skills Mahasiswa PAI Melalui Pendekatan Saintifik Dalam Implementasi Keterampilan Abad 21." Conciencia, vol. 19, no. 2, 2019, pp. 112-31.

Sit, Masganti. Psikologi Perkembangan Anak Usia Dini Edisi Pertama. Kencana, 2017.

Windarsih, Chandra Asri. "Aplikasi Teori Umpan Balik (Feedback) Dalam Pembelajaran Motorik Pada Anak Usia Dini." Tunas Siliwangi: Jurnal Program Studi Pendidikan Guru PAUD STKIP Siliwangi Bandung, vol. 2, no. 1, 2017, pp. 20-29. 